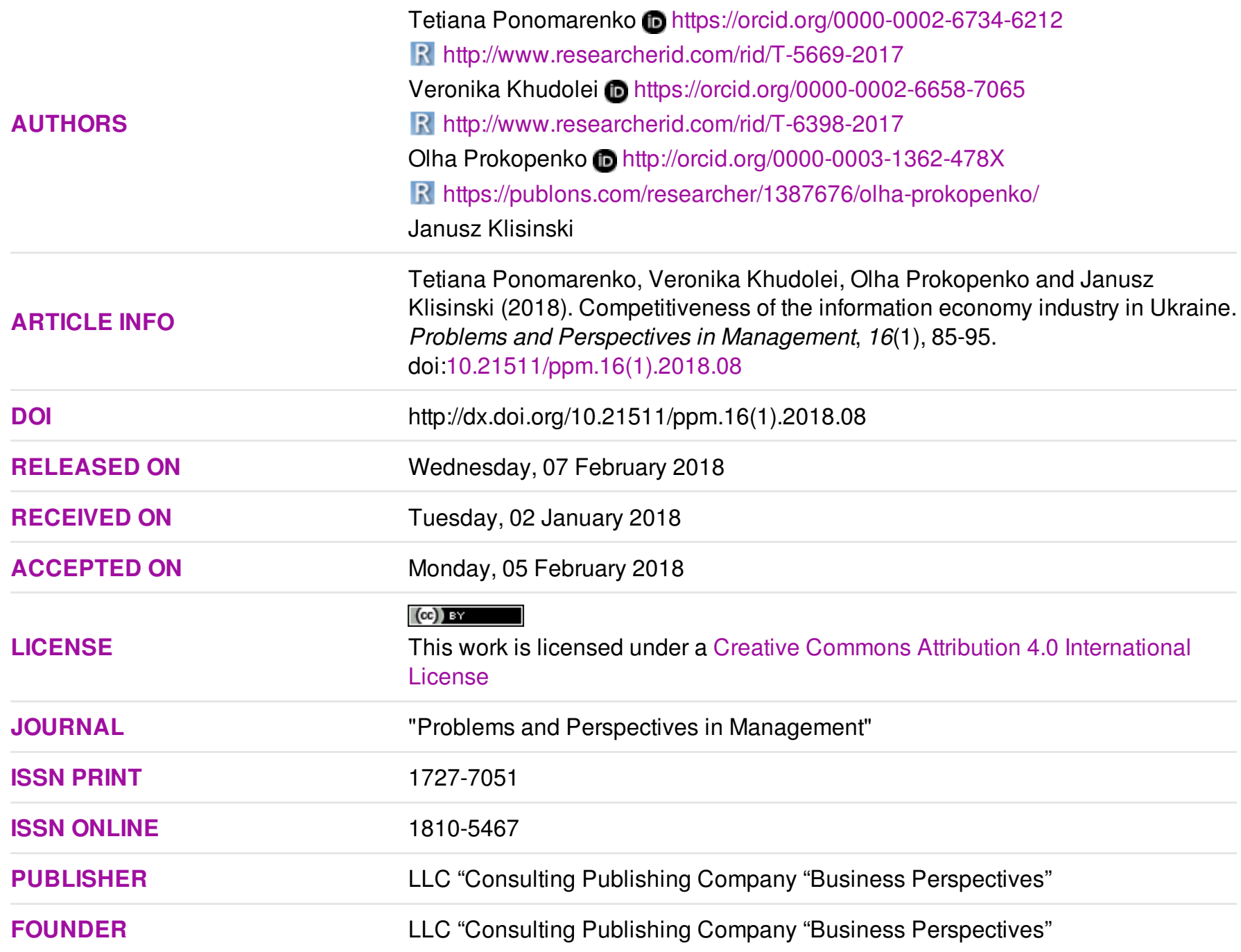

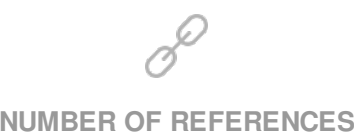

26

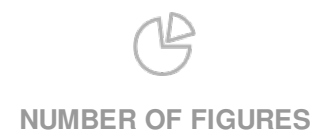

2

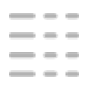

NUMBER OF TABLES

11

(C) The author(s) 2021. This publication is an open access article. 


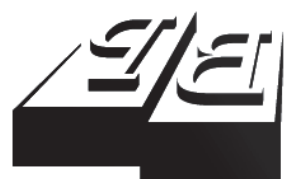

BUSINESS PERSPECTIVES

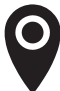

LLC "CPC "Business Perspectives" Hryhorii Skovoroda lane, 10, Sumy, 40022, Ukraine

www.businessperspectives.org

Received on: $2^{\text {nd }}$ of January, 2018 Accepted on: $5^{\text {th }}$ of February, 2018

(C) Tetiana Ponomarenko, Veronika Khudolei, Olha Prokopenko, Janusz Klisinski, 2018

Tetiana Ponomarenko, Doctor of Economics, Professor of Department of International Economics, Accounting and Finance, Yu. Buhai International University of Science and Technology, Ukraine.

Veronika Khudolei, Doctor of Economics, Rector of Yu. Buhai International University of Science and Technology, Ukraine.

Olha Prokopenko, Doctor of Economics, Professor, Professor of Management Department at the University of Bielsko-Biala, Poland; Professor of Business-Economics Department at Kyiv National University of Technology and Design, Ukraine.

Janusz Klisinski, Doctor of Economics, Head of the International Management Department at the University of Bielsko-Biala, Poland.

\section{(ㄷ) (i)}

This is an Open Access article, distributed under the terms of the Creative Commons Attribution 4.0 International license, which permits unrestricted re-use, distribution, and reproduction in any medium provided the original work is properly cited.
Tetiana Ponomarenko (Ukraine), Veronika Khudolei (Ukraine),

Olha Prokopenko (Ukraine), Janusz Klisinski (Poland)

\section{COMPETITIVENESS OF THE INFORMATION ECONOMY INDUSTRY IN UKRAINE}

\begin{abstract}
Information economy, being the newest type, in the course of formation acquires its distinctive features, which include a significant change in the needs of investors, producers, consumers and other economic relation participants. In order to achieve a competitive information economy, state support for high-tech industries is needed. It is crucial to create a clear legal framework, give boost to the formation of intellectual capital based on other countries' experience. Implementation of the strategy for high-tech industries development in Ukraine is a decisive step in creating a platform for information technology dissemination, creation of new competitive products with high added value. The purpose of the article is to investigate the transformation to the information economy, to analyze the industry competitiveness, to define the opportunities for information sphere improvement. The theoretical aspect of the emergence and formation of the information economy category is studied, the approaches to the defining this economic category and its derivatives have been studied and generalized, essential features of the information type of economic relations have been investigated, and their main components have been determined. In the article, the relationship between the level of information economy development and the competitiveness of domestic enterprises' products has been described, the factors influencing high-tech industries development in Ukraine are considered, and suggestions as for increasing the assistance to the development of knowledge-intensive sectors, including information technology, are proposed.
\end{abstract}

\section{Keywords \\ innovation, information technology, strategic resources, high-tech, telecommunications, strategy, competitiveness}

\section{JEL Classification L86, L96, O14}

\section{INTRODUCTION}

Nowadays, Ukraine is at the very beginning of the shaping an insight in the information model of the economy, which continues to grow actively under the influence of the unprecedented rapid development of information technology. Given the state interests and the interests of Ukrainian enterprises, one of the main macroeconomic tasks in a given period of time is the choice of appropriate economic development vector complying with new realities, which would correspond to the global processes, and would be able to ensure the movement of public economic energy in rapid transformation of Ukrainian society using new strategic resources. Thus, the study of the information economy development and monitoring of its impact on the domestic producers' competitiveness adds to the formation of an effective strategy of state development. While implementing information technologies and developing the regulatory framework it is important to take into account the experience of other countries that have already undergone the formation of the competitive information economy and were able to bring the production processes in the country to a new 
level. Of particular interest is the experience of Poland, one of Ukraine's closest neighbors and a member of the European Union.

In Ukraine, the regulatory framework of the high-tech industry development is presented by following documents: Draft Order of the Cabinet of Ministers of Ukraine "On approval of the strategy for the development of high-tech industries by 2025 and approval of the Action plan for its implementation", Action plan for implementation of the strategy for the development of high-tech industries by 2020 , the Strategy for the development of high-tech industries by 2025.

It is planned, by 2020, to implement the concept of High-Tech Office, which is presented by the public organization "High-Tech Office Ukraine". This organization is already engaged in projects such as: System 112 - emergency call using one telephone number, ShSD - project to overcome digital inequality, "Digital Cities - Digital Ukraine" - a project for introduction of new technologies in the Ukrainian cities, and "Cashless economy" - project for development of payment infrastructure to increase non-cash payments.

The concept of the Strategy for the high-tech industry development by 2020 also envisages the development of an export-oriented innovation ecosystem, the introduction of Digital Agenda concept, implementation of program for attraction the world's high-tech leaders to the developing production and $\mathrm{R} \& \mathrm{D}$ in Ukraine (Welcome MNC) and the promotion of the latest technologies among young people (High-Tech Nation).

By 2025, the Strategy for the development of high-tech industries plans to achieve significant level of production process intellectualization, the implementation of new information and communication technologies, and the creation of a new model for economic development - an information, innovation economy. Realization of the strategy will allow to form a competitive informational economy, improve intellectual capital of the country and reach the new level in the production.

Analysis of the information economy competitiveness taking place nowadays is vital for achieving the goals; special attention should be paid to the factors influencing its development, the opportunities and threats in this sphere as well as to the fundamental literature analysis on shaping the "information economy" definition.

\section{LITERATURE REVIEW}

It is clear today that the notion of information economy was considered in the narrowed sense, mainly from the standpoint of productive forces without taking into account other elements of the economic system, such as property, socio-economic relations, organizational and economic ties, which, according to the authors, substantially narrowed the real economic content of this concept.

Subsequently, numerous scientific concepts were used to describe the relevant stages of the economy and society development, namely: information society (Umesaou, 1963), knowledge economy and information economy (Mahlup, 1972), post-industrial society (Bell, 1971), network nation (Khilts \&
Turoff, 1978) and others. Currently, in the scientific community, the concepts of information economy and information society have been widely supported and disseminated.

Castells (1998) (Information Economy: Economics, Society, Culture) put the term of information economy into practice. His work gave an impulse to an understanding of the information role in the modern world and attempts to develop the economic theory of the information society. Castells believes that technology is a resource potential of society's development and its self-determination. At the same time, his assertion on the absolute determination of social changes solely by technology looks like an overstatement. 
Podluzhna (2017) has analyzed the influence of information and communication technologies on the economics of knowledge. The main tendencies in that sphere were examined and the measures for improvement were proposed.

Tufetulov (2007) concluded that in the information economy, the productivity and competitiveness of factors or agents (individual, enterprise, national economy) depend, first of all, on their ability to generate, process and effectively use knowledge-based information. It is general opinion that an economy based on the use of modern high-quality knowledge is the highest form of economy, because it has a unique ability to produce, distribute and use up-to-date knowledge to ensure its growth and competitiveness.

Semeniuk, Kotliarevskyi, Kniaziev and Melnikov (2017) determined the information economy importance, identified the prospects for the development, and concretized the concept of the information sphere economy.

While making conclusions to the research results, Kononova (2015) argues that, despite declared goals and the national programs adoption, state support for knowledge-intensive sectors of the economy including information technology is substantially inadequate.

Frolov, Hovorun and Ostapenko (2017) analyzed the information technology development in Ukraine during economic crisis and highlighted the main problems in the sphere. The authors proposed the forecasts based on taxonomic analysis.

It should be noted that despite the fact that the starting positions in different countries were very diverse and differed in historical, economic and cultural factors, over time, the governments of most countries - world leaders came to realize the need to unify the legislative framework in innovation, e-commerce, intellectual property, cybercrime, liberalization of the market of communication technologies and technological decisions standardization. It is these processes that ensure the acceleration of the world economy globalization, on the one hand, and the preservation of cultural uniqueness of nations, on the other.
Danylovych-Kropyvnytska (2016) defined information as a new, most recent strategic resource. The author also offered the opinion that the modern subject of economic activity is forced to adapt to a dynamic and changing environment and try to obtain a competitive advantage without further increasing the main factors of production through the effective use of information and knowledge as a strategic resource.

Voinarenko, Dzhulii and Yemchuk (2016) consider the development of information industry in Ukraine. They paid attention to the perspectives of information system and technology enhancement, especially IT industry.

Morse and Veselovska (2015) analyzed the country's economy competitiveness with indicators of network readiness, the e-government index and the global competitiveness index, and developed proposals to solve problems in information and communication technologies.

Deeper analysis of the role of information and communication technologies in Ukraine and the formation of an information society was made by Cherevko and Zhigadlo (2016).

In the article, the most reasonable definition of information economy can be a modern degree of post-industrial society development, which is characterized by the crucial importance of information products and creative resource in the shaping economic relations. Therefore, the business entities competitiveness is determined, first of all, by their ability to generate, process and effectively use the latest knowledge-based information. Knowledge-based economics, the hallmark of which is the production, dissemination and use of knowledge to ensure its growth, is a progressive stage of socio-economic relations.

\section{RESEARCH RESULTS}

The information economy is influenced by a number of technological, economic, social and spatial factors. It is crucial to analyze which socio-economic form of economic property in the specific economic structure of Ukraine best meets the requirements of the development of information 
knowledge, information equipment and technologies, in other words, the conditions for harmonious and balanced development of the country, stimulating the introduction of information products and services. The development of information and communication technologies can be analyzed both on macro and microeconomic levels. Microeconomic level is characterized by the influence of new technologies on automating the production processes of the enterprise in order to increase goods competitiveness.

At the macroeconomic level, following factors can be used to characterize the information economy: volume of GDP in information and telecommunication, global competitiveness index, network readiness index, e-government development and others.

Official data on the dynamics of commodity output volume in high-tech industries in Ukraine for 2011-2016 show the current state of information technology development in Ukraine, as one of the high-tech industries, to which this industry is included in the computer and office equipment production and software creation according to the actual share of $\mathrm{R} \& \mathrm{D}$ costs in the production cost at a level greater than 5\%. High-tech industries, in addition to information technology, according to the OECD classification, include the aerospace and pharmaceutical industries, the production of medical, high-precision and optical equipment.

Table 1. GDP of Ukraine for 2010-2017, UAH mln in actual prices (except for temporarily occupied territories)

Source: Statistical data on national calculations, Government statistics of Ukraine.

\begin{tabular}{|c|c|c|c|}
\hline \multirow[b]{2}{*}{ Years } & \multicolumn{2}{|r|}{ GDP, UAH, mln } & \multirow[b]{2}{*}{$\begin{array}{c}\text { Specific } \\
\text { weight }\end{array}$} \\
\hline & $\begin{array}{c}\text { Ukraine, in } \\
\text { total }\end{array}$ & $\begin{array}{l}\text { Including information } \\
\text { and telecommunication } \\
\text { sphere }\end{array}$ & \\
\hline 2010 & $1,079,346$ & 33,011 & 3.1 \\
\hline 2011 & $1,299,991$ & 38,390 & 2.9 \\
\hline 2012 & $1,404,669$ & 43,379 & 3.1 \\
\hline 2013 & $1,465,198$ & 48,372 & 3.3 \\
\hline 2014 & $1,586,915$ & 52,724 & 3.3 \\
\hline 2015 & $1,988,544$ & 72,596 & 3.7 \\
\hline 2016 & $2,383,182$ & 90,135 & 3.7 \\
\hline $\begin{array}{l}\text { First } \\
\text { half of } \\
2017\end{array}$ & $1,240,859$ & 48,795 & 3.9 \\
\hline
\end{tabular}

In Ukraine, there is a significant increase in the volumes of commodity output produced by the information technology industry. The volume growth is $8.9 \%$ in $2014,37.6 \%$ in 2015 , and $24.1 \%$ in 2016 as to the previous years. The analysis indicates that the share of products of the information technology industry while maintaining the trend towards growth remains low and is $3.9 \%$ (in the first half of the year). As a comparison, the information sector in developed countries forms annually from $50 \%$ to $70 \%$ of the total value added.

Given the fact that most software developers in Ukraine operate on freelance conditions, and customers are often non-resident developers, the actual cost of products created in the country in the information technology may not be sufficiently correct.

The indications from the point of view of the main trends in the field of information services and telecommunications are data on service exports and imports in this area for 2013-2016, as shown in Table 2.

Data analysis results for the period from 2013 to 2016 allow to conclude that the total cost of the IT segment products has increased by USD 150.4 $\mathrm{mln}$, or $10 \%$. This is despite the fact that the value of imports decreased by USD $277.9 \mathrm{mln}$, or $39.7 \%$, and the excess of service exports over imports in 2016 reached the maximum value of 1.2 billion dollars over the last four years and has grown by USD $795.3 \mathrm{mln}$ compared to 2013.

There is a tendency, when the growth rate of avantgarde product volumes outstrips its use in the territory of Ukraine, which significantly reduces the macroeconomic effect, given that the potential of the information economy is based not only on the creation of high-tech products, but also on its direct use.

One of the main reasons for the imbalance between the creation and use of information and technology products is low investment activity in Ukraine due to the current political situation, the specifics of doing business under oligopoly and the long-term shortage of working capital from economic entities, in connection with a significant increase in the cost of traditional types of 
Table 2. Dynamics of exports and imports of telecommunications, computer and information services in Ukraine in 2013-2016"

Source: Exports and imports dynamics, Government statistics of Ukraine.

\begin{tabular}{|c|c|c|c|c|c|c|c|}
\hline \multirow[b]{2}{*}{ Year } & \multicolumn{3}{|c|}{ Exports, USD ths } & \multicolumn{3}{|c|}{ Imports, USD ths } & \multirow[b]{2}{*}{$\begin{array}{c}\text { Net } \\
\text { balance }\end{array}$} \\
\hline & $\begin{array}{c}\text { Cost in Ukraine } \\
\text { in total }\end{array}$ & $\begin{array}{c}\text { Cost of } \\
\text { information } \\
\text { technology } \\
\text { products }\end{array}$ & $\begin{array}{c}\text { Specific } \\
\text { weight, \% }\end{array}$ & $\begin{array}{c}\text { Cost in Ukraine } \\
\text { in total }\end{array}$ & $\begin{array}{c}\text { Cost of } \\
\text { information } \\
\text { technology } \\
\text { products }\end{array}$ & $\begin{array}{c}\text { Specific } \\
\text { weight }\end{array}$ & \\
\hline 2013 & $76,662,728.4$ & $1,493,661.9$ & 1.95 & $93,146,163.2$ & $698,384.8$ & 0.75 & 1.20 \\
\hline 2014 & $53,925,104.9$ & $1,675,551.7$ & 3.11 & $57,815,664.3$ & $512,016.7$ & 0.89 & 2.22 \\
\hline 2015 & $47,348,483.5$ & $1,855,572.6$ & 3.92 & $49,046,536.9$ & $548,344.7$ & 1.12 & 2.80 \\
\hline 2016 & $45,177,884.6$ & $1,644,093,0$ & 3.64 & $50,889,500.0$ & $420,442.3$ & 0.83 & 2.81 \\
\hline
\end{tabular}

products due to increased costs for all types of energy resources.

The low investment activity in the information technology segment is not typical for the global economy, since this field is a high-marginal investment of capital, the mobility of which has increased significantly in recent decades.

It is necessary to note the Ukraine's inactivity in state support for the high-tech sectors development (Table 3).

Table 3. Dynamics of reduction in high-tech products financing from the State Budget of Ukraine, in \% as to GDP

Source: ITU Report: Information and communication technology development in the world

\begin{tabular}{c|c|c|c|c|c}
\hline \multicolumn{7}{|c}{ Years } \\
\hline $\mathbf{1 9 9 0}$ & $\mathbf{1 9 9 5}$ & $\mathbf{2 0 0 2}$ & $\mathbf{2 0 0 6}$ & $\mathbf{2 0 1 0}$ & $\mathbf{2 0 1 6}$ \\
\hline 2.3 & 0.6 & 0.4 & 0.5 & 0.3 & 0.2 \\
\hline
\end{tabular}

The refusal of state support for the scientific and innovation sphere is a bitter experience of ill-conceived decisions affecting the foundations of Ukraine's stable development. The weak competitive position of Ukraine has resulted from the absence of a strategy in the country's economic policy at a time when the creation of competitive advantages should become a strategic direction of the government's activities in ensuring the national economy competitiveness at all levels of the hierarchy.

To determine the level of information and communication technologies development in Ukraine it is important to consider the network readiness and the level of Internet access. The statistics are presented by the Kyiv International Institute of Sociology. 2,040 respondents from all regions of Ukraine (except the Crimea) were interviewed. In Luhansk and Donetsk regions, polls were conducted only in territories controlled by Ukraine. There has been a significant increase since 1997, 20162017 period is a plateau. This indicator is rather low for a country intending to integrate into the international information sphere.

As to the statistics on the characteristics of Internet users in 2017, the disproportion of Internet distribution in settlements of different sizes is decreasing. The smallest share of Internet users in villages is $51 \%$, as country people have problems with the technical capabilities of connectivity.

According to the index of economic competitiveness (the Global Competitiveness Index) (Table 4) in 2016-2017, Ukraine ranked 85th among 138 world countries, having lost six points in the year, which is a very negative signal for the world community, investors and donor countries.

Table 4. Dynamics of Ukraine's position changes in the Global Competitiveness Index ranking

\begin{tabular}{|c|c|c|c|c|c|c|}
\hline \multicolumn{7}{|c|}{ Years } \\
\hline 2010-2011 & 2011-2012 & 2012-2013 & 2013-2014 & 2014-2015 & 2015-2016 & 2016-2017 \\
\hline \multicolumn{7}{|c|}{ Number of countries analyzed } \\
\hline 139 & 142 & 144 & 148 & 144 & 140 & 138 \\
\hline \multicolumn{7}{|c|}{ Ukraine's rating } \\
\hline 89 & 82 & 73 & 84 & 76 & 79 & 85 \\
\hline
\end{tabular}


Source: Ukrainian success for 25 years: Dynamics of some social indicators (2017).

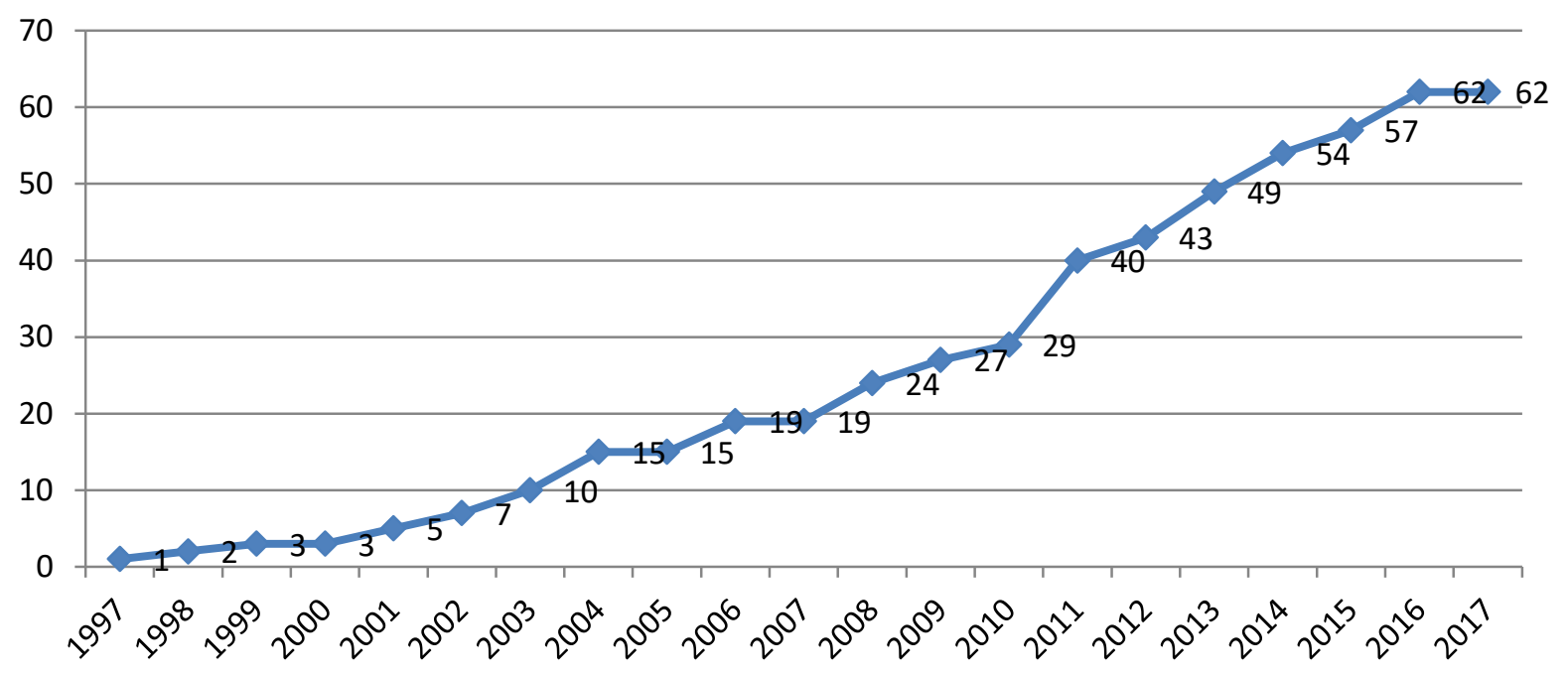

Figure 1. The proportion of adult Internet users (18+) in Ukraine, \%

According to the Global Information Technology Report 2016, the world is on the verge of a Fourth Industrial Revolution. New technologies, more potential for human development, artificial intelligence appear. But such rapid development of innovative technologies can carry certain threats, such as cyber-attacks increase, privacy issues. Therefore, the innovation processes should be gradual, the country should have all the resources to implement the technologies in order to ensure data protection and private data preservation.
Based on the statistical data of this report, one can compare the development of information technologies in Ukraine and Poland, taking similarities or greatest differences into account.

According to the Networked Readiness Index, both Ukraine and Poland show a good pace in raising the rating (Table 5). This index includes evaluation of factors such as: firm technology absorption, patenting, Internet use, innovation capacity, etc.

Source: Dynamics of Internet use in Ukraine: May 2017.

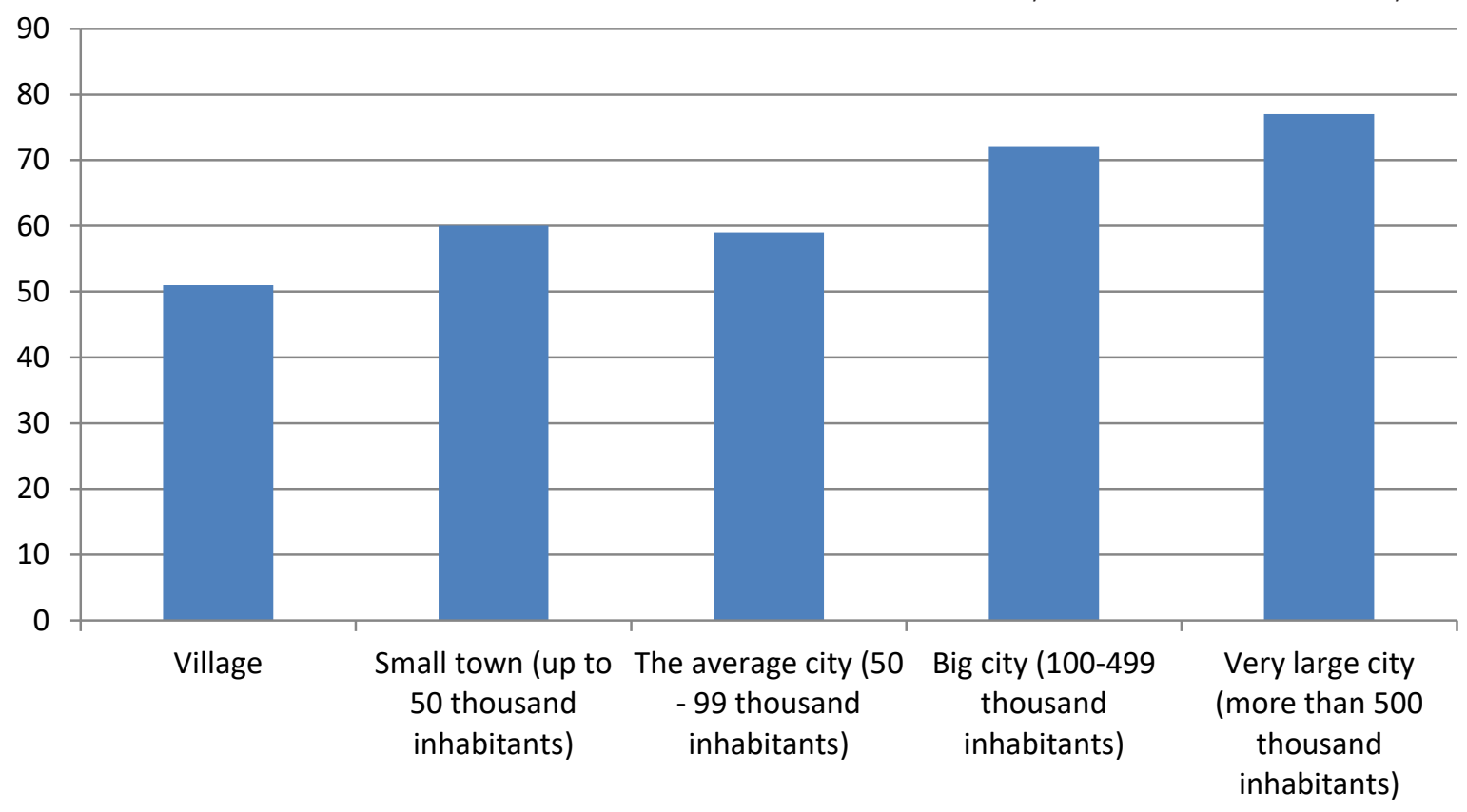

Figure 2. Share of Internet users among inhabitants of settlements of different types, \% (2017) 
Table 5. The Networked Readiness Index of Ukraine and Poland

\begin{tabular}{l|c|c|c}
\hline Country & $\begin{array}{c}\text { Rank in } \\
\mathbf{2 0 1 5}\end{array}$ & $\begin{array}{c}\text { Rank in } \\
\mathbf{2 0 1 6}\end{array}$ & $\begin{array}{c}\text { Value in } \\
\mathbf{2 0 1 6}\end{array}$ \\
\hline Ukraine & 71 & 64 & 4.2 \\
\hline Poland & 50 & 42 & 4.5 \\
\hline
\end{tabular}

The Political and regulatory environment indicator consists of factors such as: judicial independence, law-making bodies effectiveness, legal system effectiveness, intellectual property protection, ICT-related laws, software piracy rate, etc. As to procedures and days to enforce a contract, Poland is rather competitive and has good ranks that help to get the total rank - 57, while Ukraine is only on the 113th place (Table 6). In Business and innovation environment pillar Ukraine is competitive in Tertiary education gross enrollment rate - 11 rank, the country has weakest position in Total tax rate, $\%$ profits - 118, the total rank in Business and innovation environment is 67 (Table 6). Poland has better results and ranks 53th.

In Infrastructure rank, Mobile network coverage has the highest rank among other factors - 37. And the latest news in that sphere that the National Commission, which control for the information and communication, sold frequencies for $4 \mathrm{G}$ technology development in Ukraine that gives hope for further improvement in this indicator. Among Affordability factors, Ukraine ranks 2nd in Fixed broadband Internet tariffs, PPP USD/ month, as for Skills, the country has advantage in Adult literacy rate -9 rank (Table 7). In Readiness sub-index, Poland does not go much further than Ukraine and ranks 28th, Infrastructure rank is rather higher than in Ukraine, and Affordability is the first factor where Ukraine has higher position than Poland. Skills value are nearly on the same level.

In Ukraine, Mobile phone subscriptions/100 pop has the best rank among other indicators in Individual usage - 31 rank, or 144.1 in value, in Business usage, Business-to-consumer Internet use factor has advantage - 36 rank, and in Government usage, Government success in ICT promotion is ahead - 94 rank. All the ranks impact the low total Ukraine's Usage sub-index -88 , while Poland is on the 49th place (Table 8).

Ukraine's Impact sub-index (69 rank) is competitive in Knowledge-intensive jobs, \% workforce and Internet access in schools (Table 9). Such a detailed statistical overview of the indicators in the country's information and communication technology development allows to identify the weaknesses and strengths that need to be analyzed and improved. This report data revealed the main problems in the country: ICTs' impact on business models - 113 place, ICTs importance to government vision - 122, Mobile broadband subs/100 pop - 121, Intellectual property protection -120 rank, Judicial independence - 131 place. Therefore, in these areas a significant chance should occur to create competitive information economy. Poland has a good rank according to United Nations eGovernment Survey 2016, but Ukraine has rather good development perspectives (Table 10). It should be noted that in different income level categories, Poland is among High income level countries, while Ukraine is in Lower middle income category. Slight difference in indices of the two countries can be seen in the Human Capital Index

Table 6. Environment sub-index and pillars for Ukraine and Poland

\begin{tabular}{|c|c|c|c|c|c|c|}
\hline Country & $\begin{array}{l}\text { Environment } \\
\text { subindex rank }\end{array}$ & Value & $\begin{array}{c}\text { Political and } \\
\text { regulatory } \\
\text { environment rank }\end{array}$ & $\begin{array}{c}\text { Political and } \\
\text { regulatory } \\
\text { environment } \\
\text { value }\end{array}$ & $\begin{array}{c}\text { Business and } \\
\text { innovation } \\
\text { environment rank }\end{array}$ & $\begin{array}{c}\text { Business and } \\
\text { innovation } \\
\text { environment } \\
\text { value } \\
\end{array}$ \\
\hline Ukraine & 94 & 3.8 & 113 & 3.2 & 67 & 4.3 \\
\hline Poland & 48 & 4.2 & 57 & 3.9 & 53 & 4.6 \\
\hline
\end{tabular}

Table 7. Readiness sub-index and pillars for Ukraine and Poland

\begin{tabular}{l|c:c|c|c|c|c}
\hline Country & $\begin{array}{c}\text { Readiness } \\
\text { subindex } \\
\text { rank }\end{array}$ & $\begin{array}{c}\text { Readiness } \\
\text { subindex value }\end{array}$ & $\begin{array}{c}\text { Infrastructure } \\
\text { rank }\end{array}$ & $\begin{array}{c}\text { Infrastructure Affordability } \\
\text { value }\end{array}$ & $\begin{array}{c}\text { Affordability } \\
\text { rank }\end{array}$ & $\begin{array}{c}\text { Skills } \\
\text { value }\end{array}$ \\
rank & $\begin{array}{c}\text { Skills } \\
\text { value }\end{array}$ \\
\hline Ukraine & 30 & 5.7 & 51 & 4.7 & 6 & 6.6 \\
\hline Poland & 28 & 5.8 & 35 & 5.3 & 11 & 53 \\
\hline
\end{tabular}


Table 8. Usage sub-index and pillars for Ukraine and Poland

\begin{tabular}{l|c|c|c|c|c|c|c|c}
\hline Country & $\begin{array}{c}\text { Usage sub- } \\
\text { index rank }\end{array}$ & $\begin{array}{c}\text { Usage } \\
\text { sub-index } \\
\text { value }\end{array}$ & $\begin{array}{c}\text { Individual } \\
\text { usage rank }\end{array}$ & $\begin{array}{c}\text { Individual } \\
\text { usage value }\end{array}$ & $\begin{array}{c}\text { Business } \\
\text { usage } \\
\text { rank }\end{array}$ & $\begin{array}{c}\text { Business } \\
\text { usage } \\
\text { value }\end{array}$ & $\begin{array}{c}\text { Government } \\
\text { usage rank }\end{array}$ & $\begin{array}{c}\text { Government } \\
\text { usage value }\end{array}$ \\
\hline Ukraine & 88 & 3.6 & 76 & 3.9 & 63 & 3.6 & 114 & 3.1 \\
\hline Poland & 49 & 4.2 & 42 & 5.3 & 64 & 3.6 & 82 & 3.6 \\
\hline
\end{tabular}

Table 9. Impact sub-index and pillars of Ukraine and Poland

\begin{tabular}{l|c|c|c|c|c|c}
\hline Country & $\begin{array}{c}\text { Impact sub- } \\
\text { index rank }\end{array}$ & $\begin{array}{c}\text { Impact sub-index } \\
\text { value }\end{array}$ & $\begin{array}{c}\text { Economic impacts } \\
\text { rank }\end{array}$ & $\begin{array}{c}\text { Economic } \\
\text { impacts value }\end{array}$ & $\begin{array}{c}\text { Social } \\
\text { impacts } \\
\text { rank }\end{array}$ & $\begin{array}{c}\text { Social } \\
\text { impacts } \\
\text { value }\end{array}$ \\
\hline Ukraine & 69 & 3.7 & 59 & 3.4 & 75 & 4.0 \\
\hline Poland & 59 & 3.8 & 44 & 3.6 & 74 & 4.0 \\
\hline
\end{tabular}

(HCI) that consists of components such as: the combined primary, secondary and tertiary gross enrolment ratio, expected years of schooling, average years of schooling, and adult literacy rate.

As to human resources that are the base of Human Capital Index, special attention should be paid to the IT sector competitiveness in Poland and Ukraine, where the IT professionals' skills are integral to this sector success (Table 11).

It can be seen from the data that Ukraine has lower average developer's salary as compared to Poland, that is why huge US and Western European companies can save more but English proficiency is rather moderate in that country. In 2015, Ukraine ranked 4th as to the number of certified IT professionals worldwide and if the problem with foreign languages is solved, Ukraine will have good perspectives for IT sector development.
When comparing the statistical data of the two countries, the weakest points in using innovative technologies can be revealed, but in order to take the another country's experience, it is necessary to understand that Poland is a high-income country and her experience in the information technology field may not be effective in respect to Ukraine.

Timely development of information technologies with their subsequent inclusion in public processes opens up a wide range of competitive opportunities, since information largely modifies economic mechanisms and, as a result, contributes to the socio-economic development of the country. Competitiveness of the national economy subjects depends on their potential ability to respond to new products and knowledge supplied by information space.

Information technology is one of the most dynamic areas of business with high investment at-

Table 10. Ukraine's position according to the United Nations e-Government Survey 2016

\begin{tabular}{l|c|c|c|c|c}
\hline Country & Total rank & $\begin{array}{c}\text { e-Government } \\
\text { Development Index }\end{array}$ & $\begin{array}{c}\text { Online Service } \\
\text { Index }\end{array}$ & $\begin{array}{c}\text { Telecommunication } \\
\text { Infrastructure Index }\end{array}$ & $\begin{array}{c}\text { Human } \\
\text { Capital Index }\end{array}$ \\
\hline Ukraine & 62 & 0.6076 & 0.5870 & 0.3968 & 0.8390 \\
\hline Poland & 36 & 0.7211 & 0.7029 & 0.5857 & 0.8747 \\
\hline
\end{tabular}

Table 11. Comparison of the IT sphere in Poland and Ukraine

Source: Top IT Outsourcing Destinations: Ukraine vs. Poland (2016).

\begin{tabular}{l|c:c}
\hline \multicolumn{1}{c}{ Factor } & \multicolumn{1}{c}{ Ukraine } & Poland \\
\hline Number of IT professionals & 230,000 & 160,000 \\
Average developer's salary & USD 2,000 per month & USD 3,000 per month \\
Number of IT graduates entering the market annually & 30,000 & 15,000 \\
Rank in EF English proficiency index 2015 & 34 th place & 9 th place \\
Export volume of IT sphere & USD 2.5 bln & USD 7.9 bln \\
How much US and Western European companies are expecting to save if & Up to $60 \%$ of the total IT & Up to 50\% of the total \\
they give jobs to IT workers in that country & expenses & IT expenses \\
\hline
\end{tabular}


tractiveness. This means the availability of a window of opportunities for Ukraine to use the traditionally high level of specialists training in the field of information technology and computer engineering for the transformation of Ukraine into the territory with the most favorable conditions for high-intellectual products. The development and practical application of transparent pricing mechanisms could contribute to the fact that added value created from the intellectual component remained in the budget of Ukraine and contributed to the development of the economy and society as a whole. Unfortunately, for today the possibility of creative human capital accumulation is not used by the country.

The formation of the information society economy in Ukraine resulting from the information technologies development has a positive effect on modern technologies development in other economic sectors, and the modernization of technologies, in turn, influences further informatization of socioeconomic processes. Thus, the development of informatization processes against the backdrop of the eclectic structure of the Ukrainian economy, which contains elements of virtually all of the previous economic patterns with an application in the form of oligopoly and comprehensive corruption, which forms a mass of various problems for the state development, is seen as undoubtedly a significant driving factor in the country's development.

Ukrainian society informatization positively influences the expansion of the potential for raising the population's education in the country and its internationalization. This is another important consequence of using the open information space, which, under other favorable conditions, is able to increase the current quality of science and education, the level of which has always been and is a factor of long-term competitiveness of the country's economy.

The formation of the information economy in Ukraine is not revolutionary, but it develops in the industrial economy depths, in step with the global information technology development. This process involves gradual changes in practically all paradigms of the society. The ethical foundation is changing: people show themselves in an individualistic way more than before; they are aimed at the personal abilities realization and personal development; a significant percentage of public communications in virtually all areas takes place in the virtual space; society is transformed into informational, based on the production, distribution and consumption of information; information becomes a reserve for business and government in decision making and shaping public opinion. The attitude of society to information is changing: now it is perceived not as an additional opportunity, but as a separate independent, meaningful resource that should be relevant and effectively used.

Information economy as a branch of knowledge manifests itself in almost all processes taking place in the market system of Ukraine and in public administration. A significant feature of the information economy is, as well, its two-way efficiency: the information created affects the new technologies development, which, in turn, affects the further development of information space. It follows that the products of the information technology segment can become the main instrument and catalyst for the science development in Ukraine. An important condition is the formation of legal mechanisms for an adequate system of information security and copyright protection, which in itself is a rather difficult task, taking into account the dynamic development of technologies in this area.

Due to the new knowledge use, prerequisites for resource conservation, use of new energy sources and waste products are created, which is a significant positive global effect and a factor in the longterm competitiveness of the country.

Capital and labor market are undergoing a significant transformation. Today, to a large extent, labor services are based not only on professional skills, but also on individual knowledge, features and human potential. The number of traditional professions in the material production and the number of people employed is reduced and their employment in the information sphere is increasing.

Capital is becoming more informational in nature: it operates in the global economic space, mainly in information forms; in addition, there are new forms of its formation (crypto-currency) and new motion modes (blockchain technology). 
Taking into account that under severe competition on world foreign markets the country 's development potential is determined by the scientific and technical advantages, a serious step towards stimulating investments in the development of innovations in the country is required. Ukraine has the preconditions and should fully realize itself in information technology, which can become, to a certain extent, the engine of economic development against the backdrop of decline and degradation of entire sectors of the social economy, which will enable the country to take its place in the global distribution of goods and services market. Given the significant initial lag and traditionally the priority development of information technology in other countries, it is obvious that without a multidimensional state support, this will not be achieved by society. Ukraine needs an innovative development strategy and its quickest implementation, otherwise there is a risk to be left behind civilization processes.

\section{CONCLUSION}

An analysis of the information economy development in Ukraine has shown that it forms in the depths of the traditional industrial economy at a rapid pace and leads to changes in all sectors of the economy, thus becoming a separate strategically important resource and keeping the traditional types out. The researches of the dynamics of high-tech industries growth in shaping the Ukraine's GDP indicate that the volumes of this industry's production are growing at a rapid pace, but their share in the country GDP is still much lower compared to the developed countries; the dynamics of the growth of goods and services exports in this sector far outstrips their use in Ukraine, which indicates at the incomplete use of the high-tech industries potential and has negative consequences in the form of: lack of reimbursement of costs of the state for the highly skilled specialists training, the outflow of a promising labor resources, the creation of highly liquid added value outside Ukraine. All this leads to direct losses of the budget of Ukraine in the current period and in the future.

Comparing the development of information technologies in Ukraine and Poland, it can be seen that Poland has higher innovative technologies level. However, Ukraine has good chances of developing IT sector, since there is favorable environment for this, and human capital is the main strength.

At present, the Ukrainian government is significantly reducing the financing of high-tech sectors. The lack of state support for high-tech sectors of the economy, including information technology, is a strategic mistake in view of the preconditions for the further development of these industries in Ukraine, which could become the engine of the country's development as a whole and a factor in the long-term competitiveness of the economy.

\section{REFERENCES}

1. Bell, D. (1971). The post-industrial society: the evolution of an idea. Survey, 17, 102-168.

2. Castells, M. (1998). Information Age: Economy, Society and Culture. Vol. I-III. Oxford: Blackwell Publishers.

3. Cherevko, O. L., \& Zhigadlo, A. V. (2016). Роль інформаційно-комунікаційних технологій в розвитку національної економіки [Rol informatsiinokomunikatsiinykh tekhnolohii $\mathrm{v}$ rozvytku natsionalnoi ekonomiky]. Visnyk ZhDTU, 4(78), 202-210.

4. Danylovych-Kropyvnytska, M. L. (2016), Інформаційна економіка як платформа мережизації [Informatsiina ekonomika yak platforma merezhyzatsii]. Ekonomika I suspilstvo, 7, 273-278

5. Dynamics of use of Internet in Ukraine: May 2017 (2017). Retrieved from http://www.kiis. com.ua/?lang $=$ ukr $\&$ cat $=$ reports $\&$ $\mathrm{id}=705$ \&page $=3$
6. Frolov, S., Hovorun, A., \& Ostapenko, M. (2017). Prospects for the innovative development of information technology in Ukraine during economic crisis. Innovative Marketing, 13(1), 5560. http://dx.doi.org/10.21511/ im.13(1).2017.05

7. Hiltz, S. R., \& Turoff, M. (1978). The network nation: human communication via computer (528 p.). Addison-Wesley Pub. Co.

8. HiTech Office Ukraine (2018). Retrieved from http://www.htoffice.org/en/ 
9. Kononova, K.Yu. (2015). Інформаційна економіка: моделювання інноваційних процесів [Informatsiina ekonomika: modeliuvannia innovatsiinykh protsesiv] (313 p.). Kharkiv: KhNU imeni V. N Karazina.

10. Machlup, F. (1972). The Production and Distribution of Knowledge in the United States. Princeton: Princeton University Press.

11. Mazur, O. A., \& Pustovoit, S. V. (2016) Соціальна та економічна ефективність діяльності академічних технопарків України [Sotsialna ta ekonomichna efektyvnist diialnosti akademichnykh tekhnoparkiv Ukrainy]. Nauka ta innovatsii, Akademperiodika, 12(3), 63-73.

12. Morse, N. V., \& Veselovska O. V. (2015). Аналіз конкурентоспроможності економіки України через призму інформаційно-комунікаційних технологій [Analiz konkurentospromozhnosti ekonomiky Ukrainy cherez pryzmu informatsiinokomunikatsiinykh tekhnolohii]. Informatsiini tekhnolohii i zasoby navchannia, 49(5), 26-36.

13. Podluzhna, N. O. (2017). Spreading degree assessment of information and communication technologies in Ukraine and its regions. Nowadays and Future Jobs, 1(1).

14. Report ITU: Rozvytok informatsiino-komunikatsiinykh tekhnolohii u sviti. Retrieved from http://www.dut.edu.ua/ua/news/1/ category/575/view/3603

15. Science \& Technology. World Bank. Retrieved from https://data. worldbank.org/topic/science-andtechnology

16. Semeniuk, E. P., Kotliarevskyi, Ya. V., Kniaziev, S. I., \& Melnykov, O. V. (2017). Економіка інформаційної сфери: формування спеціальнонаукового категоріального аппарату [Ekonomika informatsiinoi sfery: formuvannia spetsialnonaukovoho katehorialnoho aparatu], Nauka innov., 13(3), 5-21.

17. The Global Information Technology Report (2016). World economic forum. Retrieved from http://www3.weforum.org/docs/ GITR2016/WEF_GITR_Full_Report.pdf

18. Top IT Outsourcing Destinations: Ukraine vs. Poland (2016). Retrieved from https://www.nix.com/top-it-outsourcingdestinations-ukraine-vs-poland/

19. Tufetulov, А. А. (2007). Информационная экономика и информационное общество [Informatsionnaya ekonomika i informatsionnoye obshchestvo]. Aktualnyye problem ekonomiki $i$ prava, 3, 39-45.

20. Ukrainian success for 25 years: dynamics of some social indicators (2017). Retrieved from http:// www.kiis.com.ua/?lang=ukr\&cat $=$ reports\&id $=732 \&$ page $=1 \& \mathrm{t}=5$

21. Umesao, T. (1963). Information Industry Theory: Dawn of the
Coming Era of the Ectodermal Industry. Tokyo: Asahi Hoso.

22. United Nations e-Government Survey (2016). Retrieved from http://workspace.unpan.org/ sites/Internet/Documents/UNPAN97453.pdf

23. Voinarenko, M., Dzhulii, V., \& Yemchuk, L. (2016). Development of information systems and modeling of their implementation in the business. Problems and Perspectives in Management, 14(3). http://dx.doi.org/10.21511/ ppm.14(3).2016.10

24. План заходів щодо реалізації Стратегії розвитку високотехнологічних галузей до 2020 року [Plan zakhodiv shchodo realizatsii Stratehii rozvytku vysokotekhnolohichnykh haluzei do 2020 roku]. Retrieved from http://www.me.gov.ua/ Documents/Detail?lang=ukUA\&id $=\mathrm{c} 9 \mathrm{~b} 6 \mathrm{f} 0 \mathrm{~b} 0-1 \mathrm{ed} 5-4 \mathrm{aba}-$ a25e-f824405ccc64\&

25. Статистичні дані про національні розрахунки [Statystychni dani pro natsionalni rozrakhunky] Retrieved from http://ukrstat.gov.ua/

26. Стратегія розвитку високотехнологічних галузей до 2025 року [Strategiia rozvytku vysokotekhnologichnykh haluzei do 2025 roku]. Retrieved from http://www.me.gov.ua/ Documents/Detail?lang=ukUA\&id=c9b6f0b0-1ed5-4abaa25e-f824405ccc64\& 